\title{
Trying to Turn up the Turnout: Youth Wings and the Youth Vote in the 2015 General Election
}

La Participation des jeunes lors des élections législatives de 2015 au RoyaumeUni

\section{Sarah Pickard}

\section{OpenEdition}

\section{Journals}

Electronic version

URL: http://journals.openedition.org/rfcb/503

DOI: $10.4000 / \mathrm{rfcb} .503$

ISSN: 2429-4373

\section{Publisher}

CRECIB - Centre de recherche et d'études en civilisation britannique

\section{Electronic reference}

Sarah Pickard, «Trying to Turn up the Turnout: Youth Wings and the Youth Vote in the 2015 General Election », Revue Française de Civilisation Britannique [Online], XX-3 | 2015, Online since 01 December 2015, connection on 30 April 2019. URL : http://journals.openedition.org/rfcb/503 ; DOI : 10.4000/ rfcb. 503

This text was automatically generated on 30 April 2019.

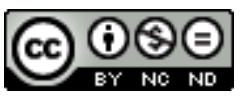

Revue française de civilisation britannique est mis à disposition selon les termes de la licence Creative Commons Attribution - Pas d'Utilisation Commerciale - Pas de Modification 4.0 International. 


\title{
Trying to Turn up the Turnout: Youth Wings and the Youth Vote in the 2015 General Election
}

\author{
La Participation des jeunes lors des élections législatives de 2015 au Royaume- \\ Uni
}

Sarah Pickard

An estimated 7.5 million 18 to 24 -year-olds were eligible to vote in the 2015 general election. ${ }^{1}$ Most had been affected by neoliberal policies and austerity measures enacted during the five years of the Conservative-Liberal Democrats coalition government. In particular, many young people suffered due to the growth of youth unemployment, the lack of affordable accommodation, the closure of youth services, the abolition of the Educational Maintenance Allowance (EMA), the cuts to the higher education budget and the increase in university tuition fees. ${ }^{2}$ Conversely, opposition parties made concerted efforts to appeal to young people by proposing specific "youth-friendly" policies. For example, the Labour Party pledged to reduce university tuition fees to $£ 6,000$ per annum, whereas the Green Party promised to scrap them completely. Both parties claimed they would enfranchise 16 and 17-year-olds in future elections. At the same time, the Conservative Party, the Labour Party and the Liberal Democrats made manifesto pledges that were favourable to the "grey vote," for example, they all promised to maintain the triple lock on the State pension. David Cameron also vowed to protect universal pensioner benefits, such as the Winter Fuel Payments, free bus passes and free television licences.

The relationship between young people and traditional politics featured prominently throughout the 2015 election campaign. The predominant mass media narrative was that British youth is uninterested in politics and politicians. ${ }^{3}$ Indeed, there is a "widely-held view that today's generation of youth is increasingly reluctant to play a role in political life, and is dismissive of the formal political process and democratic institutions". ${ }^{4}$ Such pessimistic and normative labelling corresponds to an overwhelmingly negative portrayal of young people in the media in general. ${ }^{5}$ Evidence of the apparent political disaffection resides in 
the general election turnout rates of 18 to 24 -year-olds, which are considerably lower than those of other age groups. During the election campaign, barely any mention was made of political party youth wings and their membership.

In this article, I draw together these different strands, in order to answer the following question: What was the relationship between young people and traditional electoral politics during the 2015 general election? ${ }^{6}$ Thus, the article first discusses voter registration and voter turnout of 18 to 24-year-olds. It goes on to explore the role played by the youth wings of traditional political parties in encouraging political participation among young people. The article ends with an analysis of the outcome of the 2015 general election in terms of the youth vote.

\section{Participating in traditional politics}

Political participation tended to be divided into two main forms in the past. First, traditional (also called conventional or institutional participation), which includes registering on the electoral roll, voting in elections and being a member of a political party. Second, non-traditional (also called unconventional or non-institutional participation), which encompasses protesting, dissenting and being involved in civil disobedience. ${ }^{7}$ Increasingly, a third kind of identity politics or issue-based political participation is being acknowledged, which covers deliberate acts, such as product boycotts and lifestyle choices, such as veganism. Thus, the repertoire of political participation has become more diverse ${ }^{8}$ and the meaning of politics, political acts and political participation, i.e. ways of doing politics has been widened. ${ }^{9}$ Young people are especially associated with newer forms of political participation, probably to the detriment of traditional politics, such as registering and voting in general elections, on which this article focuses. ${ }^{10}$

\section{Registering to vote}

In order to vote in an election in Britain, it is necessary to be on the electoral roll (also called electoral register). British citizens become entitled to vote at the age of 18 , although the electoral register also includes records of "attainers": 16 and 17-year-olds who will turn 18 during the period in which the register is in force. Young people tend to have lower registration rates than other age groups. At the end of 2010, 56\% of 18 to 24 year-olds were on the electoral register, compared with more than $94 \%$ of those aged over 65, according to the Electoral Commission; ${ }^{11}$ the Hansard Society provided similar statistics in 2014:

The youngest age groups, particularly $18-24 \mathrm{~s}$, are those most likely to say they are not registered or to claim not to know. Only $69 \%$ of respondents in this age group say they are registered compared to a national average of $90 \%$. In contrast, respondents aged $45+$ all reported registration levels of $96 \%$ or above. ${ }^{12}$

This phenomenon exists for a variety of reasons, including pragmatic and logistic ones. Young people are more likely to be mobile, change addresses and live in temporary accommodation, which makes it harder for local authorities to register them. According to the Hansard Society, "given that young people (18-34) are those most likely to be in rented accommodation there is a clear association between age, housing tenure and electoral registration levels." ${ }^{13}$ This is all the more relevant as a greater proportion of young people is going into 
higher education than in the past. Potential first time voters are also more likely to lack knowledge about how to register, or find it difficult because they do not have the experience of older age groups.

Various institutional efforts have been made in recent years to make inclusion on the electoral roll easier, in order to boost registration rates, especially among young people and stem the perceived crisis of democracy. ${ }^{14}$ First, rolling registration, also called continuous registration, was introduced by the Labour Government in February 2001, ${ }^{15}$ so that it is now possible to be added to the electoral roll with a local authority throughout the year. Second, registration has been mandatory since 2001, when it became obligatory for the head of a household to list all the eligible voters living at that address. ${ }^{16}$ Third, online registration is now possible. Fourth, the gap between when registration closes and voting takes place has been narrowed. In 2015, the deadline to register was Monday 20 April, 17 days before polling day. ${ }^{17}$ However, in a bid to reduce electoral fraud, the Conservative-Liberal Democrat coalition introduced individual electoral registration (IER) during 2014. University halls of residence and parents can no longer register a young person on his/her behalf. For Georgia Gould, the change was likely to exacerbate the decrease in voter registration among younger people ${ }^{18}$ and it was predicted that thousands of young people would fall off the electoral register thus not be able to vote. ${ }^{19}$

In March 2015, it was estimated that $70 \%$ of 18 to 24 -year-olds were registered to vote (representing eleven per cent of the total registered electorate), which led to speculation that the youth turnout in the 2015 general election could be the largest since 1964 and have "a significant impact on the result". ${ }^{20}$ This optimism was partially due to the exceptionally high turnout rate among young people in the Scottish Independence referendum on 18 September 2014. Crucially, 16 and 17-year-olds were enfranchised and about $80 \%$ of those eligible to register to vote did so $(109,533)$, whereas the turnout for these first time voters was $75 \%$, compared to a national average of $84.59 \% .{ }^{21}$

\section{Turning out to vote}

There is a clear link between registration rates and turnout rates; according to the Electoral Commission, this correlation is especially manifest among young people:

One of the most important reasons for declining levels of registration is increasing disengagement with politics and decreasing turnout at elections as the desire to participate in elections remains a key driver for registering. Findings presented in this report show that people who say they are less likely to vote are less likely to be registered. Disengagement with traditional party politics is even more marked among young people (only $24 \%$ said they were certain to vote in a general election compared to $60 \%$ or above for those aged 55 or over) and, with mobility, is likely to be the main reason behind the low level of completeness among this group. ${ }^{22}$

Turnout rates at elections are calculated according to the proportion of the population who vote that are actually registered to vote. Turnout rates exclude people who are not on the electoral roll..$^{23}$ Therefore, if someone is not registered, he or she will not be included in the electoral turnout rate. Older and more educated individuals tend to have high participation rates in elections. However, young people in Britain have had consistently lower turnout rates than other age groups for general elections since the 1960s. This is despite a much bigger proportion of young people today having a high level of educational attainment - usually a factor linked to greater turnout rates - compared to older generations. Moreover, the gap between age groups has been widening since the 
mid-1960s and especially since 1997. The different rates between age groups now is therefore greater in Britain than in other advanced democracies, to the extent that for Richard Berry and Anthony McDonnell, in Britain "highly educated young people are less likely to vote than older people with much lower levels of attainment". ${ }^{24}$

David Denver argues that four interconnected social factors are associated with low turnout: being young (the most important one), being unmarried, living in privately rented accommodation, and being residentially mobile. ${ }^{25}$ Higher levels of non-voting by these groups can be explained in terms of isolation from personal and community networks, which are characteristic of stable communities that encourage conformity or the norm of voting. ${ }^{26}$

Varying political participation rates can be understood in terms of cost and benefit, ${ }^{27}$ hence some young people might not see the point (or the value) of making the effort to vote ${ }^{28}$ The way the first-past-the-post electoral system works in general elections favours larger established parties and leads to the under-representation of certain smaller political parties, which tend to gain a greater proportion of their votes from young people, such as the Green Party. ${ }^{29}$ This under-representation contributes to the feeling among British youth that voting is not worth it.

Not going to the polls can be explained by other logistical factors: young people might have other things to do on the polling day that seem more important, they might be too busy, ${ }^{30}$ or the polling station might not be accessible enough for them. Significantly, in the May 2015 general election, it was not possible to vote online or via a Smartphone. The Electoral Commission and the Electoral Reform Society have both acknowledged that evoting (electronic voting) would increase turnout especially among first time voters. The Digital Democracy Commission was set up and is chaired by John Bercow, the Conservative Speaker of the House of Commons who was once leader of the Young Socialists. It recommended in a report published early 2015 that "By 2020, secure online voting should be an option for all voters". ${ }^{31}$ Yet e-voting already exists in other countries, such as Estonia, which introduced it in 2007 for parliamentary elections. The lack of opportunity to vote via new technologies is a non-negligible drawback for young people of whom almost two thirds wanted to be able to vote online in the general election, while a similar amount felt the voting system was failing. ${ }^{32}$ Voting online would be a way to reach young people who often change addresses and whose lives are led online.

Other reasons why young people abstain are 'a feeling that their views are not represented by any particularly party (38 per cent),' 'an inability to distinguish between political parties ( 23 per cent)' and 'a lack of diversity amongst candidates (22 per cent)'. ${ }^{33}$ Another cause of not going to the polls is that some young people feel disaffected ${ }^{34}$ with politics or alienated ${ }^{35}$ from MPs, for example, due to their behaviour in the House of Commons and during the expenses scandal..$^{36}$ But young people were especially affected by the broken 2010 electoral promise of the Liberal Democrats with Nick Clegg's U-Turn on university tuition fees, which increased distrust of politics in general: 'Voter cynicism is most prevalent among young people'. ${ }^{37}$

Such disillusionment and distrust in traditional politics can lead to an active and deliberate decision not to participate, which Nicole Gallant calls 'avoidance'. ${ }^{38}$ It can be a way of refusing the normative political status quo. Russell Brand initially advocated abstention in the 2015 general election, in order not to endorse what he considered a deeply unsatisfactory political system in need of a 'revolution' ${ }^{39} \mathrm{He}$ outlined his stance on 
Twitter (he has a vast Twitter following), in a guest editorship of the New Statesman, a subsequent interview with Jeremy Paxman (23 October 2013) and in his book:

I don't feel inclined to rally youth to put an $\mathrm{x}$ in a box on a little ballot ticket but on the doors of those who will be spared when the plague descends. For we are at a turning point: the exploitation has now reached a pitch where the disenfranchised and exploited can look to a culpable minority with vengeful eyes. [...] There are some ideas worth voting for, no party in any civilised nation will propose them, because they are not there to represent us and to ensure that the necessary change to protect us and our planet but to simply maintain the current system. ${ }^{40}$

Russell Brand went on to endorse Caroline Lucas of the Green Party and then the Labour Party leader Ed Miliband.

\section{Supporting a political party}

Political party affiliation acts as a motivator and encourages people to turn out to vote. However, young people in Britain today are less likely to identify with or support a political party than older age groups. According to the 2014 British Social Attitudes Survey, $19 \%$ of 16 to 24 -year-olds supported a political party compared with $56 \%$ of people over 75-years-old. ${ }^{41}$ The Hansard Society has similar statistics:

Younger respondents are much less likely to claim support for a party than older age groups: just $23 \%$ of $18-24$ s claim to be at least a 'fairly strong' supporter of a party compared to $44 \%$ of those aged $75+$ who say the same. Conversely, just over half of 18-24 year olds (53\%) declare themselves not to be a supporter of any political party but this is a view shared by only $24 \%$ of those aged $75+{ }^{42}$

Membership of political parties has decreased considerably in Britain over the past two generations. ${ }^{43}$ In 2015 , a tiny proportion of the population is a member of a political party:

Membership of the three main political parties is at a historic low: less than $1 \%$ of the UK electorate is now a member of the Conservative, Labour or Liberal Democrat Party, compared to $3.8 \%$ in 1983 . Latest membership estimates from the parties suggest that the Conservative Party has 149,800 members, the Labour Party 190,000 and the Liberal Democrat Party $44,000 .^{44}$

The percentage of British youth who are members of a political party is even smaller. ${ }^{45}$ For Richard Keen, "Young people seem to have become particularly disassociated from political parties, although all age ranges surveyed demonstrate a loss of allegiance". ${ }^{46}$ This drop can partially be explained by the lifecycle effect, i.e. the older you become the more civic-minded and more responsible you become and the more interested in politics you become. However, the current rates of party affiliation and party membership are much lower than in previous decades. Fewer young people today support political parties than previous cohorts of young people. ${ }^{47}$ There is a "generational" change, as all groups are less likely to be members of a political party than in the past. Over the previous thirty years, each successive cohort of young voters has been less likely to identify with a political party than its previous cohort. When the lifecycle effect is combined with the generational effect, the forecast for traditional political participation among young people is bleak. 


\section{Campaigning among youth wings}

All the mainstream English political parties have youth wings (also called youth sections, youth factions, youth branches, or youth organisations), which are aimed mainly at 16 to 30-year-olds, especially further and higher education students. They have all undergone name changes over the years, often to distance themselves from unfavourable and/or extreme reputations. The Labour Party first had Leagues of Youth, followed by the Young Socialists, and now it has two youth wings, Young Labour (for 14 to 26-year-olds) and Labour Students. ${ }^{48}$ The Conservative Party started with Young Britons and then Young Conservatives, before adopting the name Conservative Future, in 1998. ${ }^{49}$ The Liberal Democrats once had the National League of Young Liberals, then the Liberal Democrat Youth and Students (LDYS); the current entity has been Liberal Youth (for students and young people under-26) since 2008. The Green Party of England and Wales has had Young Greens (for 18 to 30-year-olds and students) since 2002. ${ }^{50}$ Lastly, UKIP's youth wing (for under-thirties) called Young Independence has existed since 2007; it also has the smaller UKIP Students Association. ${ }^{51}$

Youth wings have an ambivalent relation with parent parties..$^{52}$ They fulfil various roles, such as supplying "foot soldiers" and activists for the parent party during election campaigns, providing young candidates and to a lesser degree financial funds through membership fees. Most have played a very limited role in policy formulation and decision making within the parent party from whom they receive some degree of funding. Very little has been written about British youth wings, except for works by Zig Layton-Henry on Labour and Conservative youth wings in the 1970s and a PhD thesis on the same subject by Matthew Lamb in 2002. There is little doubt that the dearth of research on youth wings is linked to the opaque relations between youth wings with main parties, the lack of real power invested in youth wings, their poor communication and the high turnover of membership. It is also linked to the lack of reliable information regarding membership data and the relatively small number of young people seemingly involved.

Indeed, it is impossible to obtain reliable and precise statistics on membership of youth wings. ${ }^{53}$ In the past, the recording of membership tended to be more informal; demographic data such as age were not noted and parties were prone to exaggeration. ${ }^{54}$ Today, political parties are still not obliged to publish membership statistics and youth wings have been reluctant to reveal their figures. The situation is further complicated by the regular turnover of members as they reach the upper age limit and differing age brackets for each youth wing. Nonetheless, there exists a great deal of competition among youth wings regarding membership numbers. Conservative Future (CF) claimed on its website at the time of the general election to be the "largest youth political organisation in the UK with 15,000 members under 30" (a figure it had been using since 2007). ${ }^{55}$ However, the Young Greens, declared on its blog mid-April that "the \#GreenSurge has been incredible, with the Young Greens growing from about 1,300 at the end of 2013, to more than 17,700 now - more than Conservative Future"'. ${ }^{56}$ Young Greens also boasted via Twitter that was the biggest youth wing, which led to scathing tweets from Young Labour, the only youth wing to criticize another youth wing on Twitter during the election campaign:

@YoungGreenParty, 13 April 2015, "We are now the largest youth party in the whole of the UK with over 17,700 members!" 
@YoungLabourUK, 20 April 2015, “Hey @YoungGreenParty just FYI you are not the biggest youth party. We understand stats aren't your strong point but over $22,000>17,700 "$

also all our members are under 27 rather than up to 30 . Plus we have Labour Students on top of those numbers. \#justsaying

However, Young Labour and Labour Students do not reveal membership statistics and they did not appear of their website. Liberal Youth does not give out its figures either. Lastly, Young Independence "UKIP's Youth Wing for the under thirties" stated that it had "over 3,000 members", ${ }^{57}$ although elsewhere on the site it says 3,500 and it tweeted statistics that did not add up:

@Yiofficial, 30 March 2015, Today YI membership passes 3,500 alongside UKIP's 44,000. Be part of our movement, join us:

@Yiofficial, 16 April 2015, YI Membership DOUBLES in year!

@Yiofficial, 25 April 2015, YI membership this morning jumped to 3,600, up by 100

in just one week!

Therefore, youth wings insisted on their membership statistics and vied to be the biggest youth wing, although, altogether, these six youth wings accounted for fewer than 50,000 members.

During the 2015 general election campaign, youth wings used social media to varying degrees in order to encourage voter registration and voter turnout among first time voters. Official youth wing websites were employed in a very limited way as they were rarely changed or updated. Official Facebook pages were revised more frequently and posts were made, in particular by Liberal Youth and Young Greens. Similarly, these two youth wings were the most active on Twitter, the preferred form of social media among most youth wings. The exception was Conservative Future that neither posted any messages on its official Facebook page nor tweeted from its Twitter account. The main themes in the Facebook posts and tweets were campaigning for a specific policy, the parent party, or a particular candidate and to a lesser degree encouraging young people to come and join them on the campaign. Hardly any mention was made of registering to vote except by Young Labour and Young Greens.

\section{Evaluating the outcomes}

Prior to the 2015 general election, there were various measures and drives to encourage young people to be active citizens engaged with traditional politics and thus to register on the electoral roll and to vote. ${ }^{58}$ In particular, not-for-profit organisations campaigned vigorously to incite young people to engage in politics by registering and voting, so that politicians listen to and act on the specific interests of British youth. New technologies were at the heart of efforts. For example, the youth volunteering charity vinspired led a "\#Swing the Vote" campaign, the not-for-profit organisation Bite the Ballot modelled a campaign on the American "Rock the Vote", ${ }^{59}$ whilst the National Union of Students (NUS) organized “\#GenerationVote." Initiatives encouraging young people to become engaged in politics included Smartphone apps, vlogging (video blogging) and social media campaigns aiming to transform how young people think about politics. Youth wings of political parties also promoted registering to vote and turning out to vote.

No precise data is available on how many young people actually voted on 7 May 2015 because general elections are secret ballots and exit polls do not collect demographic information. Statistics have been obtained for recent general elections through 
aggregated opinion polls (Ipsos MORI), exit polls and specific academic studies, such as the British Election Study (BES). After an unprecedented low in 2001, general election participation rates among 18 to 24-year-olds increased in 2005 and 2010, but remained far lower than other age groups (see Table 1 and Figure 1). The national average turnout for all age groups in the 2015 general election was 66 per cent. According to the British Election Study 2015, 58 per cent of young people, aged 18 to 24, turned out to vote, ${ }^{60}$ whereas the Ipsos MORI statistics, obtained by aggregating the data from election polls and other surveys, were considerably lower with 43 per cent turnout among 18 to 24year-olds. ${ }^{61}$ Whilst there is a sizeable difference between the British Election Study and the Ipsos MORI figures, it remains that both reveal substantially lower turnout among young people than other age groups and the drop in turnout among 18 to 24 -year-olds has been stemmed.

Regarding the preferences of young people who did vote in the 2015 general election, statistics reveal salient differences in their voting patterns compared to other age groups (see Table 2 and Figure 2). The Conservative Party obtained 27\% of votes among 18 to 24 year-olds, but $47 \%$ of votes among $65+$ year-olds. Similarly, UKIP obtained $8 \%$ of votes among 18 to 24 -year-olds, but $17 \%$ of votes among $65+$ year-olds. Conversely, the Labour Party was the most popular political party among the 18 to 24 age group (43\%), whereas its popularity decreased as the age of voters increased, reaching $23 \%$ among the $65+$ age group. Likewise, the Green Party was also more popular among the youngest voters (8\%) than the oldest voters (2\%). In other words, the younger the voter, the more likely he/she was to vote for the Labour Party or the Green Party and less likely he/she was to vote for the Conservative Party or UKIP. The statistics also show that in the 2015 general election there was a steep fall in votes for the Liberal Democrats from 30\% in 2010 to $5 \%$ in 2015, suggesting among other things, an ongoing discontent with Nick Clegg's U-turn on university tuition fees in 2010.

Therefore, whilst Liberal Youth were the most active on social media during the election campaign, this did not translate into votes for the Liberal Democrats. Obviously, many other factors were involved and we cannot know the proportion of votes that would have been cast for the Liberal Democrats if Liberal Youth had not led a dynamic online campaign.

One striking phenomenon in relation to young people and politics regarding the 2015 general election, is the increased membership of youth wings before and after the poll. Liberal Youth does not give out its figures, but on 19 May 2015, it claimed that its membership increased dramatically immediately after the 2015 general election to 7,300. ${ }^{62}$ Similarly, Labour Students bragged on 10 June 2015: "Want to get involved in the largest student wing of any political party in the U.K?[...] Our membership has gone up by a massive $40 \%$ since the general election, thousands of you have put your disappointment to one side and decided to get organised to make a difference". ${ }^{63}$

Table 1: Voter turnout (of registered voters), \%, general elections 1964-2015, UK

\begin{tabular}{|l|l|l|l|}
\hline year & all age groups (\%) & $\begin{array}{l}18-24 \text { year-olds (\%) } \\
\text { BES* }\end{array}$ & $\begin{array}{l}\text { 18-24 year-olds (\%) } \\
\text { Ipsos MORI** }\end{array}$ \\
\hline $1964^{* * *}$ & 77.1 & 76.4 & N/A \\
\hline
\end{tabular}




\begin{tabular}{|l|l|l|l|}
\hline $1966^{* * *}$ & 75.8 & 60.5 & N/A \\
\hline 1970 & 72.0 & 64.9 & N/A \\
\hline $1974 \mathrm{~F}$ & 78.8 & 70.2 & N/A \\
\hline 19740 & 72.8 & 62.5 & N/A \\
\hline 1979 & 76.0 & 62.5 & N/A \\
\hline 1983 & 72.7 & 63.9 & N/A \\
\hline 1987 & 75.3 & 66.6 & N/A \\
\hline 1992 & 77.7 & 67.3 & 68 \\
\hline 1997 & 71.4 & 54.1 & 60 \\
\hline 2001 & 59.4 & 40.4 & 39 \\
\hline 2005 & 61.3 & 38.2 & 37 \\
\hline 2010 & 65.0 & 51.8 & 43 \\
\hline 2015 & 66.1 & 58.0 & 44 \\
\hline
\end{tabular}

\section{SOURCES:}

*Aliyah DAR, Elections Turnout. Standard Note SN/SG/1467. House of Commons Library, 2013, p. 4, based on re-analysis of datasets British Election Study (BES), HC Library Research Paper 03/59.

**Ipsos MORI, How Britain Voted since October 1974, 2010. Ipsos MORI, How Britain Voted in 2015, 2015.

***THE VOTINg AgE WAS DECREASED FROM 21 TO 18 IN 1969. 
Figure 1: Voter turnout (of registered voters), \%, general elections 1964-2015, UK

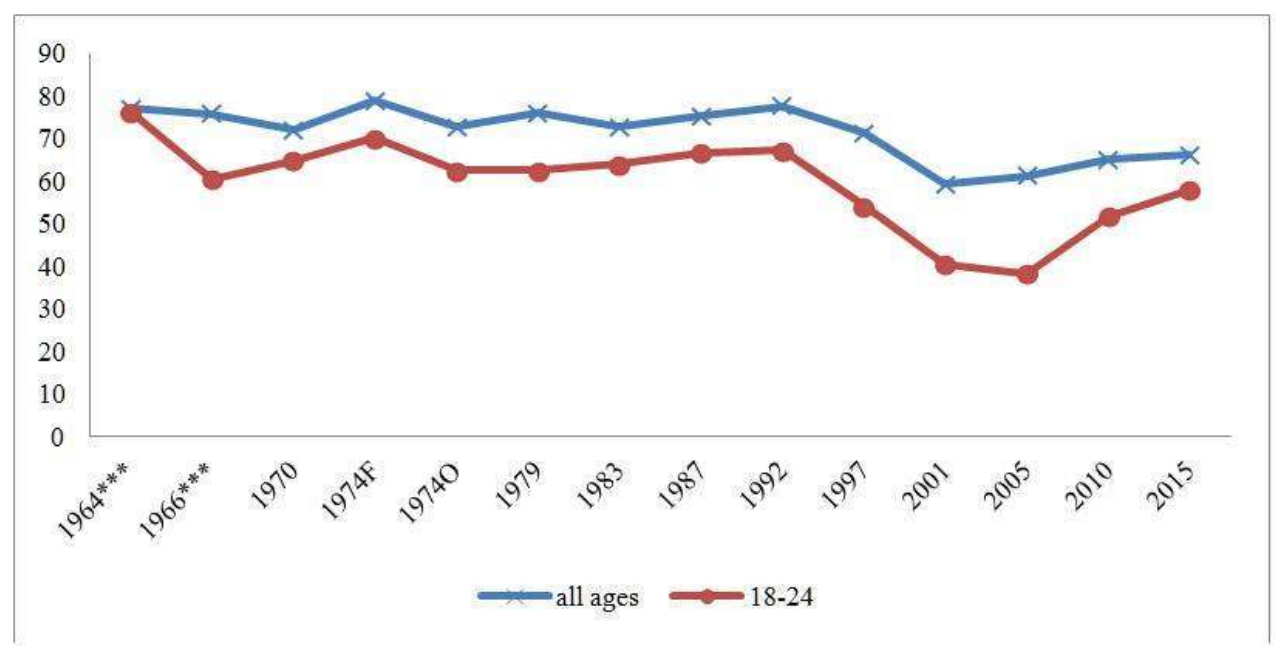

Sources:

Ipsos MORI, How Britain Voted since October 1974, 2010. Ipsos MORI, How Britain Voted in 2015, 2015.

Sources: Ipsos MORI, How Britain Voted since October 1974, 2010. Ipsos MORI, How Britain Voted in 2015, 2015.

Table 2: Voting for each political party, \%, according to age group, general election, 2015 (2010), UK

\begin{tabular}{|l|l|l|l|l|l|l|}
\hline age group & $\begin{array}{l}\text { Labour } \\
\text { Party }\end{array}$ & $\begin{array}{l}\text { Conservative } \\
\text { Party }\end{array}$ & Liberal Democrats & $\begin{array}{l}\text { Green } \\
\text { Party }\end{array}$ & Ukip & Others \\
\hline $\mathbf{1 8 - 2 4}$ & $\mathbf{4 3 ( + 1 2 )}$ & $\mathbf{2 7}(-3)$ & $\mathbf{5 ( - 2 5 )}$ & $\mathbf{8}$ & $\mathbf{8}$ & $\mathbf{9}$ \\
\hline $\mathbf{2 5 - 3 4}$ & $36(+6)$ & $33(-2)$ & $7(-22)$ & 7 & 10 & 7 \\
\hline $\mathbf{3 5 - 4 4}$ & $35(+4)$ & $35(+1)$ & $10(-16)$ & 4 & 10 & 6 \\
\hline $\mathbf{4 5 - 5 4}$ & $33(+5)$ & $36(+2)$ & $8(-18)$ & 4 & 14 & 5 \\
\hline $\mathbf{5 5 - 6 4}$ & $31(+3)$ & $37(-1)$ & $9(-4)$ & 2 & 14 & 7 \\
\hline $\mathbf{6 5 +}$ & $23(-8)$ & $47(+3)$ & $8(-14)$ & 2 & 17 & 3 \\
\hline All & $\mathbf{3 1}(+\mathbf{1})$ & $38(+1)$ & $\mathbf{8}(-16)$ & 4 & 13 & 6 \\
\hline
\end{tabular}


Figure 2: Voting for each political party, \%, according to age group, 2015 (2010) General Election, UK

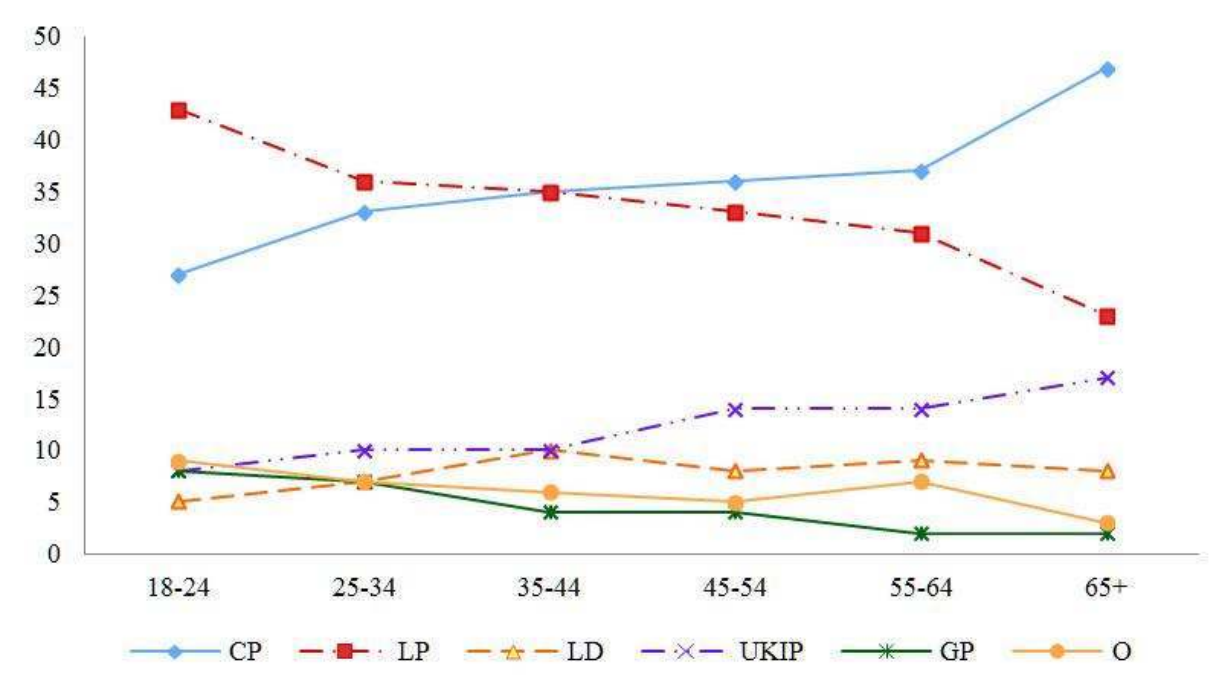

Source: Adapted by the author from: Ipsos MORI, Final Aggregate Analysis, How Britain Voted, (General Election), 2015

Figure 2: Voting for each political party, \%, according to age group, general election 2015 (2010), UK

Source: Adapted by the author from: Ipsos MORI, Final Aggregate Analysis, How Britain Voted, (General Election), 2015

\section{Conclusion}

The turnout rate of 18 to 24-year-olds was slightly higher in the 2015 general election than in the 2010, but it remained considerably lower than the national average. Left-wing political parties gained a greater proportion of their votes from younger people who turned against the Liberal Democrats compared to the previous general election. Membership of all youth wings increased before and after the 7 May 2015 polling day. These facts reveal a growing interest among young people in traditional politics and the scope for harnessing the youth vote in the future.

For this to be achieved, politicians need to address the fundamental issue that the way traditional politics is carried out in Britain is unattractive to many young people. This situation probably suits many politicians, as illustrated by their lack of financial and political investment in youth policy, youth wings and the youth vote in general. This reinforces the impression that young people are not taken seriously by politicians, contrary to the older members of the electorate who have a higher turnout rate.

Institutional politics needs to change in order to be more attractive and relevant to first time voters. First, the voting age should be reduced to 16 in order to get young people involved in politics whilst they are still within the framework of secondary education. Second, voter registration among young people should be encouraged more and registration should be possible on polling day. Third, e-voting should be launched to make voting up to date and relevant to young people who live their lives online - no 
party has committed to initiating online voting. ${ }^{64}$ Still not being able to vote online in 2015 might be explained by politicians lacking interest in the section of the population most likely to be interested in this type of voting: young people. Fourth, social media campaigns aimed at youth should be improved via the injection of skills and funds by parent parties. Fifth, parent parties should take their youth wings seriously, as they can be valuable allies in the traditional politicization of young people. The autonomy of youth wings can be a good when it confers respect and trust from the parent party. However, the freedom with which youth wings are imbued can also reflect a lack of interest from parent parties. Sixth, politicians should take an interest in young people's views and lives. Lastly, youth policy and policy in general should take more into account the specific situation of young people.

However, George Osborne, Chancellor of the Exchequer, announced in his 8 July 2015 budget statement that the cap on university tuition fees will be increased, higher education maintenance grants will be replaced by loans and housing benefit will be scrapped for 18 to 21-year-olds. It is therefore possible that during the Conservative Party's 2015-2020 term of office the relationship between young people and politics will shift away from the ballot box and towards political protest.

\section{BIBLIOGRAPHY}

BERRY, Richard and MCDONNELL, Anthony. Highly Educated Young People are Less Likely to Vote than Older People with Much Lower Levels of Attainment. Democratic Audit and London School of Economics, 2014, (http://www.democraticaudit.com/?p=2752)

BESSANT, Judith. Democracy Bytes: New Media and New Politics and Generational Change. Basingstoke: Palgrave Macmillan, 2014, 304 p.

BRAND, Russell. Revolution. London: Century, 2014, 372 p.

BRITISH ELECTION STUDY (BES). British Election Study, 2015, (http://

www.britishelectionstudy.com)

COLLIN, Philippa. Young Citizens and Political Participation in a Digital Society: Addressing the Democratic Disconnect. Studies in Childhood and Youth. Basingstoke: Palgrave Macmillan, 2015, $200 \mathrm{p}$.

CHORLEY, Matt. “Two Million Young People Will Not Vote,” Daily Mail, 6 May 2014.

CREWE, Ivor, et al. "Non-voting in British General Elections 1966-October 1974," pp. 38-109 in Colin CROUCH (ed.). British Political Sociology Yearbook, 3. London: Croom Helm, 1977, 304 p.

DAR, Aliyah. Elections Turnout. Standard Note SN/SG/1467. London: House of Commons Library, 2013, 19 p.

DENVER, David and HANDS, Gordon. "Issues, Principles or Ideology? How Young Voters Decide." Electoral Studies, 9(1), 1990, pp. 19-36. 
DENVER, David, et al.. Elections and Voters in Britain. Third edition. Basingstoke: Palgrave Macmillan, 2012, 212 p.

DIGITAL DEMOCRACY COMMISSION. Open Up. London: 20 January 2015, (http:// www.parliament.uk/business/commons/the-speaker/speakers-commission-on-digitaldemocracy/ddc-news/digital-democracy-commission-report-publication)

EDWARDS, Rick. None of the Above. Your Vote is Your Voice. Don't Stay Silent. London: Simon \& Schuster, 2015, $269 \mathrm{p}$.

ELECTORAL COMMISSION, The Quality of the 2014 Electoral Registers in Great Britain. Research into the last registers produced under the household registration system. London: The Electoral Commission, 2014, $86 \mathrm{p}$.

ELECTORAL COMMISSION. Scottish Independence Referendum. Report on the Referendum held on 18 September 2014. London: The Electoral Commission, 2014, 169 p.

FIELDHOUSE, Edward. et al.. British Election Study. Internet Panel Wave 2, 2014, (http:// www.britishelectionstudy.com/data-object/2015-british-election-study-internet-panel-wave-2)

GALLANT, Nicole. Young People and Politics in Quebec: Participation, Protest, Avoidance. Copenhagen, Denmark: Journal of Youth Studies conference. March 2015.

GOULD, Georgia. Wasted. How Misunderstanding Young Britain Threatens Our Future. London: Little, Brown, 2015, 407 p.

HACKETT, Claire. "Young People and Political Participation," pp. 74-80 in Jeremy ROCHE and Stanley TUCKER (eds.). Youth in Society. Second edition. London: Sage, 2004, 288 p.

HANSARD SOCIETY. Audit of Political Engagement 11. The 2014 Report, with a Focus on the Accountability and Conduct of MPs. London: Hansard Society, 2014, (http:// www.hansardsociety.org.uk/wp-content/uploads/2014/04/Audit-of-PoliticalEngagement-11-2014.pdf)

HAY, Colin. Why We Hate Politics. Cambridge: Polity Press, 2007, 200 p.

HEIDAR, Knut. "Party Membership and Participation", pp. 301-315 in Richard KATZ and William CROTTY (eds.), Handbook of Party Politics. London: Sage, 2006, 640 p.

HENN, Matt and FOARD, Nick. Young People and Politics in Britain. How do Young People Participate in Politics and What can be Done to Strengthen their Political Connection? (Briefing Paper). Nottingham: Nottingham Trent University, 2012.

HENN, Matt and WEINSTEIN, Mark. "Young People and Political (in)Activism: Why Don't Young People Vote?" Policy and Politics, 34(3), 2006, pp. 517-534.

HENN, Matt, WEINSTEIN, Mark and WRING, Dominic. “A Generation Apart? Youth and Political participation in Britain." British Journal of Politics and International Relations, 4(2), 2002, pp. 167-192.

HENN, Matt; WEINSTEIN, Mark; FORREST, Sarah. “Uninterested Youth? Young People's Attitudes towards Party Politics in Britain.” Political Studies, 53(3), 2005, pp. 556-578.

HM GOVERNMENT. The Electoral Register and the Open Register. Overview, 2015, (https:// www.gov.uk/electoral-register/overview)

Ipsos MORI. How Britain Voted in 2010. 2010a, (http://www.ipsos-mori.com/researchpublications/ researcharchive/poll.aspx?oItemId=2613) 
Ipsos MORI. How Britain Voted Since October 1974. 2010b, (https://www.ipsos-mori.com/ researchpublications/researcharchive/101/How-Britain-Voted-Since-October-1974.aspx? view=wide)

Ipsos MORI. How Britain Voted in 2015. 2015 (https://www.ipsos-mori.com/researchpublications/ researcharchive/3575/How-Britain-voted-in-2015.aspx?view=wide)

KENDALL, Liz. "Over 200,000 Young People have Fallen off the Electoral Register: Time to Get Them Back." New Statesman, 5 February 2015, (http://www.newstatesman.com/politics/2015/02/ over-200000-young-people-have-fallen-electoral-register-time-get-them-back)

LAYTON-HENRY Zig. “The Young Conservatives 1945-70.” Journal of Contemporary History, 8(2) 1973, pp. 143-156.

LAYTON-HENRY Zig. “Labour's Lost Youth.” Journal of Contemporary History, 11(2), 1976, pp. 275-308.

LAMB, Matthew. Young Conservatives, Young Socialists and the Great Youth Abstention: Youth Participation and Non-Participation in Political Parties. PhD thesis. University of Birmingham, 2002, 372 p. (http://etheses.bham.ac.uk/518/1/Lamb03PhD_A1a.pdf)

LEWIS, Helen. “Apathy or Antipathy? Why So Few Young People Vote," The Guardian, 19 April 2015, (http://www.theguardian.com/society/2015/apr/19/why-young-people-dont-vote-apathyor-antipathy-election-2015)

LOADER, Brian, et al. (eds.). The Networked Young Citizen. Social Media, Political Participation and Civic Engagement. London and New York: Routledge, 2014, 228 p.

MARSH, David et al. Young People and Politics in the UK: Apathy or Alienation? Basingstoke: Palgrave Macmillan, 2007, 246 p.

MORTON, Rebecca. “TV Debates and the General Election: The Largest Youth Turnout Since 1964?” Shout Out UK, 7 May 2015, (http://www.shoutoutuk.org/2015/05/07/tv-debates-general-electionlargest-youth-turnout-since-1964)

MYCOCK, Andrew and TONGE, Jon. "The Party Politics of Youth Citizenship and Democratic Engagement." Parliamentary Affairs, 65(1), 2012, pp. 138-161.

NORRIS, Pippa. Democratic Phoenix: Reinventing Political Activism. New York: Cambridge University Press (CUP), 2002, 308 p.

OFFICE FOR NATIONAL STATISTICS (ONS). “Annual Mid-year Population

Estimates, 2014" Statistical Bulletin. London: ONS, 25 June 2015, (http://www.ons.gov.uk/ons/ dcp171778_406922.pdf)

PAGE, Ben (ed.). The Shock of the New? The Menace of 2015. British Social Attitudes Survey, July 2014, ( https://www.ipsos-mori.com/Assets/Docs/News/ben-page-shock-of-the-new-ccn-2014.pdf)

PICKARD, Sarah, et al. (eds.). Les Politiques de Jeunesse au Royaume-Uni et en France: Désaffection, Répression et Accompagnement à la Citoyenneté. Paris: Presses de la Sorbonne Nouvelle (PSN), 2012, $271 \mathrm{p}$.

PICKARD, Sarah. "Productive Protest? The Contested Higher Education Reforms in England under the Coalition Government”, pp. 93-106 in Emmanuelle Avril \& Johann Neem (eds.), Democracy, Participation and Contestation: Civil Society, Governance and the Future of Liberal Democracy. London \& New York: Routledge, 2014, 332 p.

PICKARD, Sarah. "The Trouble with Young People These Days: Deviant Youth, the Popular Press and Politics in Contemporary Britain." 'Labelling the Deviant. Othering and Exclusion in Britain 
from Past to Present.' Revue Française de Civilisation Britannique (RFCB) - French Journal of British Studies, 19(1), 2014, pp. 91-122, (http://www.cercles.com/rfcb/rfcb19-1/rfcb-XIX-1.pdf)

PICKARD, Sarah. “A Conservative Future? Youth and the Conservative Party." 'Le Parti Conservateur.' Observatoire de la Société Britannique, 4, 2007, pp. 75-93.

PICKARD, Sarah. Politics, Protest and Young People: Political Participation and Dissent in $21^{\text {st }}$ Century Britain. Basingstoke: Palgrave Macmillan, 2017. [forthcoming]

PICKARD, Sarah. "Sleaze, Freebies and MPs: The British Parliamentary Expenses and Allowances Scandal ", pp. 117-14 in David FÉE and Jean-Claude SERGEANT (eds.). Éthique, Politique et Corruption au Royaume-Uni. Aix-en-Provence: Presses Universitaires de Provence, 2013, 213 p.

PICKARD, Sarah. "The Nature of Environmental Activism among Young People in Britain" in David HAIGRON and Brendan PRENDIVILLE (eds.). Political Ecology and Environmentalism in Britain. [forthcoming 2016]

PICKARD, Sarah. "The Youth Vote and Electoral Communication in the UK and the USA, 2005-2008”, pp. 107-127 in Renée DICKASON, David HAIGRON and Karine RIVIÈRE DE FRANCO (eds.). Stratégies et Campagnes Électorales en Grande-Bretagne et aux États-Unis. Paris: L'Harmattan, 2009,205 p.

PICKARD, Sarah. "What's the Point? The Youth Vote in the 2005 General Election." 'Les Elections législatives de 2005 au Royaume-Uni.' Revue Française de Civilisation Britannique (RFCB), 13(3), 2005, pp. 21-32.

PIRIE, Madsen and WORCESTER, Robert. The Big Turn-Off. London: Adam Smith Institute, 2000, 40 p.

SANDERS, David et al. The 2005 General Election in Great Britain. Report for the Electoral Commission. British Election Study (BES), 1979-2005, 49 p.

SAVIGNY, Heather. "Media, Politics and Empowerment”, pp. 13-23 in Richard SCULLION, et al. (eds.). The Media, Political Participation and Empowerment. London and New York: Routledge, 2013, $280 \mathrm{p}$.

SLOAM, James. “The 'Outraged Young': How Young Europeans are Reshaping the Political Landscape.” Political Insight, 4(1), 2013, pp. 4-7.

SLOAM, James. “The Outraged Young”, pp. 161-179 in Brian LOADER, et al. (eds.). The Networked Young Citizen. Social Media, Political Participation and Civic Engagement. London and New York: Routledge, 2014, 228 p.

STOKER, Gerry. Why Politics Matters. Basingstoke: Palgrave Macmillan, 2006, 240 p.

SWADDLE, Kevin and HEATH, Anthony. Official and Reported Turnout in the British General Election of 1987. British Journal of Political Science, 19(4), pp. 537-551.

TRANMER, Jeremy. "From Young Socialists to Young Labour: The Changing Face of Left-wing Youth Politics in Britain", pp. 45-58 in Sarah PICKARD, et al. (eds.), Les Politiques de Jeunesse au Royaume-Uni et en France: Désaffection, répression et accompagnement à la citoyenneté. Paris: PSN, 2012, $271 \mathrm{p}$.

VAN BIEZEN, Ingrid, et al.. "Going, Going ... Gone? The Decline of Party Membership in Contemporary Europe.” European Journal of Political Research, 51(1), 2012, pp. 24-56.

WE ARE SOCIAL. Digital, Social and Mobile 2015 Report. 2015, (http://wearesocial.sg/blog/2015/01/ digital-social-mobile-2015) 
YOUGOV. Green Party Membership is Booming - But it May Count for Little on Polling Day, 20 February 2015, (https://yougov.co.uk/news/2015/01/20/green-party-membership-booming-it-may-countlittle)

Websites

Bite the Ballot, (http://bitetheballot.co.uk)

Conservative Future, (http://www.conservativefuture.com; https://www.facebook.com/ ConservativeFuture; https://twitter.com/consfuture)

Electoral Commission, (http://www.electoralcommission.org.uk)

ElectUK app, (http://info.tcs.com/ElectUK.html)

Labour Students (http://www.labourstudents.org.uk; https://www.facebook.com/labourstudents ; https://twitter.com/labourstudents)

League of Young Voters, (http://www.leagueofyoungvoters.co.uk)

Liberal Youth (http://www.liberalyouth.org; https://www.facebook.com/liberalyouth; https:// twitter.com/liberalyouth)

National Union of Students (NUS), (http://www.nus.org.uk)

Rock!Enrol, (http://www.rockenrol.me)

Social Media London, (http://socialmedialondon.co.uk)

Stand Up and Be Counted (SUBC), (https://standup.news.sky.com/app/skyfeed)

vInspired, (https://vinspired.com)

Votes at 16, (http://www.votesat16.org)

Young Greens (http://www.younggreens.org.uk; https://www.facebook.com/younggreens; https://twitter.com/younggreenparty)

Young Independence (https://www.facebook.com/YoungIndependence; http:// www.youngindependence.org.uk; https://twitter.com/yiofficial)

Young Labour (http://www.younglabour.org.uk; https://www.facebook.com/YoungLabourUK; https://twitter.com/younglabouruk)

\section{NOTES}

1. According to official statistics, there were nearly six million 18 to 24 -year-olds in the United Kingdom mid-2014, which represented about $11 \%$ of the total United Kingdom population of 64.6 million. There were approximately 1.53 million 16 and 17-year-olds (ONS, 2015).

2. Sarah PICKARD, "Productive Protest? The Contested Higher Education Reforms in England under the Coalition Government," pp. 93-106 in Emmanuelle AVRIL \& Johann NEEM (eds.), Democracy, Participation and Contestation: Civil Society, Governance and the Future of Liberal Democracy, London \& New York: Routledge, 2014.

3. For example, Matt CHORLEY, "Two Million Young People Will Not Vote", Daily Mail, 6 May 2014; Helen LEWIS, "Apathy or Antipathy? Why So Few Young People Vote", The Guardian, 19 April 2015. 
4. M. HENN and N. FOARD, Young People and Politics in Britain. How do Young People Participate in Politics and What can be Done to Strengthen their Political Connection? (Briefing Paper), Nottingham: Nottingham Trent University, 2012, p. 3.

5. Sarah PICKARD, “The Trouble with Young People These Days: 'Deviant' Youth, the Popular Press and Politics in Contemporary Britain." 'Labelling the Deviant. Othering and Exclusion in Britain from Past to Present,' Revue Française de Civilisation Britannique, 19 (1), 2014, pp. 91-122. See also: Clare HACKETT, "Young People and Political Participation," pp. 74-80 in J. ROCHE \& S. TUCKER (eds.). Youth in Society, Second edition. London: Sage, 2004, p. 74.

6. This article only deals with England rather than the whole of the United Kingdom due to differing policies because of devolution of power.

7. Pippa NORRIS, Democratic Phoenix: Reinventing Political Activism, New York: Cambridge University Press, 2002, p. 222.

8. James SLOAM, "The Outraged Young," pp. 161-179 in B. LOADER, A. VROMEN and M. XENOS (eds.). The Networked Young Citizen. Social Media, Political Participation and Civic Engagement, London and New York: Routledge, 2014, p. 163.

9. Judith BESSANT, Democracy Bytes: New Media and New Politics and Generational Change, Basingstoke: Palgrave Macmillan, 2014.

10. See Sarah PICKARD, Politics, Protest and Young People: Political Participation and Dissent in $21^{\text {st }}$ Century Britain, Basingstoke: Palgrave Macmillan [forthcoming 2017].

11. Electoral Commission, Great Britain's Electoral Registers 2011, London: Electoral Commission, 2011, p. 31.

12. Hansard Society, Audit of Political Engagement 11. The 2014 Report, with a Focus on the Accountability and Conduct of MPs, London: Hansard Society, 2014, p. 41.

13. Op. cit.

14. Philippa COLLIN. Young Citizens and Political Participation in a Digital Society: Addressing the Democratic Disconnect. Studies in Childhood and Youth, Basingstoke: Palgrave Macmillan, 2015, p. 2.

15. David DENVER, et al, Elections and Voters in Britain, Third edition, Basingstoke: Palgrave Macmillan, 2012, p. 30;

Sarah PICKARD, “What's the Point? The Youth Vote in the 2005 General Election" 'Les Elections législatives de 2005 au Royaume-Uni.' Revue Française de Civilisation Britannique, 13(3), 2005, p. 22.

16. In Britain, registration is obligatory according to Section 23 of the Representation of the People (England and Wales) Regulations 2001, and those who do not are liable to a fine.

17. HM Government. The Electoral Register and the Open Register. Overview, 2015.

18. Georgia GOULD, Wasted. How Misunderstanding Young Britain Threatens Our Future. London: Little, Brown, 2015, p. 49

19. The Electoral Reform Society suggested 800,000 people aged 18 to 21 would not be able to vote because they were not on the electoral roll, whereas Labour MP Liz Kendall predicted the number would be even greater: Liz KENDALL, "Over 200,000 Young People have Fallen off the Electoral Register: Time to Get Them Back.” New Statesman, 5 February 2015.

20. Rebecca MORTON, "TV Debates and the General Election: The Largest Youth Turnout Since 1964?" Shout Out UK, 7 May 2015.

21. Electoral Commission, Scottish Independence Referendum. Report on the Referendum held on 18 September 2014. London: The Electoral Commission, 2014, p. 67.

22. Electoral Commission, The Quality of the 2014 Electoral Registers in Great Britain. Research into the last registers produced under the household registration system, 2014, p. 5.

23. David DENVER et al, 2012, op. cit., p. 31. The voting age was lowered from 21 to 18 in 1970, which 'added some 3 million young people to the register.' 
24. R. BERRY and A. MCDONNELL, Highly Educated Young People are Less Likely to Vote than Older People with much Lower Levels of Attainment. Democratic Audit and London School of Economics, 13 March 2014 (http://www.democraticaudit.com/?p=2752)

25. David DENVER et al., 2012, op. cit., p. 41.

26. I. CREWE, T. FOX and J. ALT, "Non-voting in British General Elections 1966-October 1974," pp. 38-109 in Colin CROUCH (ed.), British Political Sociology Yearbook, 3. London: Croom Helm, 1977.

27. K. SWADDLE and A. HEATH, "Official and Reported Turnout in the British General Election of 1987" British Journal of Political Science, 19 (4), 1989, pp. 537-551.

28. Sarah PICKARD, "What's the Point? The Youth Vote in the 2005 General Election." 'Les Elections législatives de 2005 au Royaume-Uni', Revue Française de Civilisation Britannique, 13(3), 2005, pp. 21-32.

29. YOUGOV, Green Party Membership is Booming - But it May Count for Little on Polling Day, February 2015.

Sarah PICKARD, “The Nature of Environmental Activism among Young People in Britain" in D. H AIGRON and B. PRENDIVILLE (eds.), Political Ecology and Environmentalism in Britain [forthcoming 2016].

30. M. PIRIE and R. WORCESTER, The Big Turn-Off, London: Adam Smith Institute, 2000, pp. 11-12.

31. Digital Democracy Commission, Open Up, London: 20 January 2015.

32. Ibid.

33. Rebecca MORTON, 2015, op. cit.

34. For an overview of young people and political disaffection, see M. HENN and M. WEINSTEIN, "Young People and Political (in)Activism: Why Don't Young People Vote?", Policy and Politics, 34 (3), 2006, pp. 517-534.

35. David MARSH et al., Young People and Politics in the UK: Apathy or Alienation?, Basingstoke: Palgrave Macmillan, 2007.

36. Sarah PICKARD, "Sleaze, Freebies and MPs: The British Parliamentary Expenses and Allowances Scandal," pp. 117-141 in D. FÉE and J-C SERGEANT (eds.). Éthique, Politique et Corruption au Royaume-Uni, Aix-en-Provence: PUP, 2013.

37. Colin HAY, Why We Hate Politics, Cambridge: Polity Press, 2007, p. 42

38. Nicole GALLANT, "Young People and Politics in Quebec: Participation, Protest, Avoidance", Copenhagen, Denmark: Journal of Youth Studies Conference, March 2015.

39. Russell BRAND, 23 October 2013 in interview with Jeremy PAXMAN, BBC 2, Newsnight: 'It is not that I am not voting out of apathy. I am not voting out of absolute indifference and weariness and exhaustion from the lies, treachery and deceit of the political class that has been going on for generations [...]. Stop voting, stop pretending, wake up, be in reality now. Time to be in reality now. Why vote? We know it's not going to make any difference already.'

40. Russell BRAND, Revolution, London: Century, 2014, pp. 79-80.

41. Ben PAGE, "The Shock of the New? The Menace of 2015." British Social Attitudes Survey, July 2014, p. 48. Question: 'Do you think of yourself as a supporter of any one political party? Pre-war (born before 1945) $=56 \%$; Baby boomers $($ born 1945-1965) $=40 \%$; Generation X $($ born 1966-1979) $=$ 30\%; Generation Y (born 1980-1999) = 19\%; Generation Z (born after 2000).'

42. Hansard Society, Audit of Political Engagement 11. The 2014 Report, with a focus on the accountability and conduct of MPs. London: Hansard Society, 2014, p. 45.

43. David DENVER, et al., 2012, op. cit.

44. Richard KEEN, Membership of UK Political Parties, SN/SG/5125. London: House of Commons Library, 30 January 2015, p. 1 (www.parliament.uk/briefing-papers/sn05125.pdf)

45. Ingrid V AN BIEZEN, "Going, Going ... Gone? The Decline of Party Membership in Contemporary Europe.” European Journal of Political Research, 51(1), 2012, pp. 24-56.

Knut, HEIDAR, Party Membership and Participation. Handbook of Party Politics. London: Sage, 2006, pp. 301-315. 
46. Richard KEEN, 2015, op. cit., p. 11

47. Georgia GOULD, 2015, op. cit., p. 49. 'The decline in party affiliation is most stark for the young. In 1991, 29 per cent of fifteen-to twenty-four-year-olds supported a political party; in 2011 it was 15.8 per cent compared with 57.8 per cent of over-seventy-fives.'

48. For a comprehensive summary of the history of the Labour Party's youth wings, see Jeremy $T$ RANMER, "From Young Socialists to Young Labour: The Changing Face of Left-wing Youth Politics in Britain," pp. 45-58 in Sarah PICKARD, et al.. Les Politiques de Jeunesse au Royaume-Uni et en France: Désaffection, Répression et Accompagnement à la Citoyenneté. Paris: Presses de la Sorbonne Nouvelle , 2012.

49. For a comprehensive summary of the history of the Conservative Party's youth wings, see Sarah PICKARD, "A Conservative Future? Youth and the Conservative Party." 'Le Parti Conservateur Britannique.' Observatoire de la Société Britannique, 4, 2007, pp. 75-93.

50. Sarah PICKARD, 2016, op. cit.

51. Other political parties in Britain have youth wings, which have undergone name changes. The BNP (the British Nationalist Youth Movement, Young BNP, Student BNP and BNP Crusaders). The SNP (Young Scots for Independence, Federation of Student Nationalists, SNP Students) and Plaid Cymru (CymruX and Plaid Cymru Youth).

52. Mathew LAMB, Young Conservatives, Young Socialists and the Great Youth Abstention: Youth Participation and Non-Participation in Political Parties. PhD thesis. University of Birmingham, 2002.

53. No political party youth wing responded to my requests for official membership figures.

54. Sarah PICKARD, 2007, op. cit.

55. Conservative Future, 7 May 2015, (http://www.conservativefuture.com)

56. Young Greens, 16 April 2015, (http://younggreens.org.uk/ygblog/2015/04/16/our-futureelection-2015/\#comments).

57. Young Independence, 16 April 2015 , 'membership of UKIP's youth wing has surpassed 3,500 members, head and shoulders above Liberal Youth's membership numbers. This is an enormous increase of 104\%, or 1,800 members, since March 2014', (http://www.youngindependence.org.uk/about)

58. A. MYCOCK and J. TONGE, "The Party Politics of Youth Citizenship and Democratic Engagement." Parliamentary Affairs, 65(1), 2012, pp. 138-161.

59. Sarah PICKARD, "The Youth Vote and Electoral Communication in the UK and the USA, 2005-2008," pp. 107-127 in R. DICKASON, D. HAIGRON and K. RIVIÈRE DE FRANCO (eds.). Stratégies et Campagnes Électorales en Grande-Bretagne et aux États-Unis. Paris: L'Harmattan, 2009.

60. British Election Study (BES), (http://www.britishelectionstudy.com/news-category/2015general-election/2015).

61. Ipsos MORI, How Britain Voted 2015, 2015.

62. Liberal Youth, 19 May 2015, 'Since polling day something awesome has been happening, people are joining the Liberal Democrats in their thousands. Why? Because the British people want to stand up for liberty, equality and freedom. Because we want a society that is united, tolerant and fair. Liberal Youth's membership has gone up by $160 \%$ - and we now have over 7,300 members are growing more and more everyday.', (http://www.liberalyouth.org/news)

63. Labour Students, 10 June 2015, 'We were all disappointed with the result on May 8th. A Toryovernment means harsh cuts for the very poorest in our communities. This disappointment however, has led to thousands of you joining us to fight back against the Tories, fight against inequality in our society, and fight for a better future for our generation.', (http://www.labourstudents.org.uk/ a_fresh_start_for_labour_students)

64. Rick EDWARDS. None of the Above. Your Vote is Your Voice. Don't Stay Silent. London: Simon \& Schuster, 2015, p. 7. 


\section{ABSTRACTS}

The political participation of 18 to 24-year-olds in British general elections is substantially lower than for other age groups. As a result, young people are frequently labelled in the media as being disaffected with traditional politics. This article explores the relationship between young people and traditional politics within the context of the 2015 general election in the United Kingdom. It addresses voter registration, electoral turnout, party preferences and youth wings of mainstream political parties in England: Conservative Future, Labour Students, Young Labour, Liberal Youth, Young Greens and Young Independence. The article reveals that whilst voter turnout among young people increased in 2015 and membership of youth wings grew, political institutions clearly did not invest time and money in the youth vote.

La participation politique des jeunes aux élections législatives au Royaume-Uni est inférieure à celle des autres tranches d'âge depuis longtemps. De ce fait, les 18 à 24 ans sont souvent étiquetés dans les médias comme une population qui rejette la politique traditionnelle. Cet article explore les relations entre les jeunes et la politique traditionnelle dans le contexte des élections législatives au Royaume-Uni du 7 mai 2015. Nous analysons l'enregistrement des jeunes sur les listes électorales, la participation électorale des jeunes, les préférences politiques des jeunes et les sections jeunes des partis politiques traditionnels. Si la participation politique des jeunes et l'adhésion aux sections jeunes ont augmenté, ce n'est pas le cas de l'intérêt qui leur est porté par les instituions politiques.

\section{INDEX}

Mots-clés: vote des jeunes, sections jeunes des partis politiques, jeunesse, participation électorale, taux de participation

Keywords: youth vote, youth wings, young people, political participation, voter turnout

\section{AUTHOR}

\section{SARAH PICKARD}

Université Sorbonne Nouvelle 